\title{
The effects of changing environment and human activities on the Arctic: Drivers and challenges in Svalbard
}

\author{
(Short Communication)
}

\author{
Barbora Padrtová
}

Department of International Relations and European Studies, Faculty of Social Studies, Masaryk University, Joštova 218/10, 60200 Brno, Czech Republic

\begin{abstract}
Climate change brings several layers of challenges to the Arctic. On the one hand, we can observe increased human activities that create potential for economic development especially in mining, oil and gas industry, shipping, fisheries and tourism. On the other hand, these economic benefits pose a risk to the environment, local populations and traditional livelihood of the Indigenous peoples. In the following three years (20202022), recently established interdisciplinary team investigates the impact of climate change and human activities on natural environment in the Arctic. The team is composed of eight scientists with different specialization from three faculties of the Masaryk University - Faculty of Social Studies, Faculty of Science, and Faculty of Law. The research focuses on both the challenges and risk assessment in terrestrial ecosystems. The relation of natural environment changes to the human-to-environment interaction is investigated, as well as the consequences for the geopolitical, legal and security developments in the Arctic region. Based on gained findings, risks analysis and recommendations for mitigating the impact of environmental changes on the natural environment and population in the specific Arctic territories will be done. The research directly contributes to encouraging interdisciplinary innovative approach with high added value and international impact. These innovative aspects of the project lie in the interdisciplinary character of the Arctic research across different specializations - natural science, social science and law, which has not been combined and investigated yet. Additionally, the project is unique due to its specific science communication and dissemination of research findings, which aims at four levels of audiences - (i) academic community, (ii) policymakers, (iii) general public, and (iv) students.
\end{abstract}

Key words: Arctic region, security, environmental changes, human activity, geopolitical challenges

DOI: $10.5817 /$ CPR2020-1-8

Received May 7, 2020, accepted July 15, 2020.

*Corresponding author: B. Padrtová < padrtova@mail.muni.cz>

Acknowledgements: The author expresses her thanks to the project ARCTIC Centre for Human-toEnvironment Oriented Studies: Impact of Climate Change and Human Activities in the Arctic (ARCTOS MU, MUNI/G/1540/2019). 


\section{Introduction}

Since the beginning of the $21^{\text {st }}$ century, international attention and global interest in the North have intensified rapidly. At the same time, the geo-strategic importance of the Arctic region has grown. It is beyond doubt that the Arctic is experiencing a transformative change. Driven by the interacting forces of climate change and globalization, the region is changing significantly in environmental, geo-economic and geopolitical terms (Padrtová and Trávníčková 2017). As a consequence of global climate change, the Arctic is warming twice as fast as the average temperature rise of the rest of the planet. The most visible and immediate effect is a decline in the Arctic Ocean sea ice extent and melting of terrestrial glaciers ([1]- AMAP 2011, Láska et al. 2012).

Ongoing global warming of atmosphere is caused by several factors, among which anthropogenic emissions of greenhouse gases play a dominant role. Climate models also predict higher increase in the temperature at the far north on the Earth, compared to the global average. Recently, the trend of rise in the air temperature has been documented for several weather station located at Svalbard archipelago. It is, however, still impossible to determine exactly how much of the atmospheric warming and co-occurring rise in precipitation in Svalbard is caused by natural variations in the climate, and how much might be attributed to the increased anthropogenic emissions of greenhouse gases.

Long-term data series on air temperature are available for the period of 18992016. Recently, the air temperature trends were evaluated and analyzed. The analysis shows a clear trend of an increase $\left(0.3^{\circ} \mathrm{C}\right.$ per decade) with more pronounced increase found in winter and spring $\left(0.36^{\circ} \mathrm{C}\right.$ per decade and $0.43^{\circ} \mathrm{C}$ per decade, respectively). Since the year 2000 , however, there have been several exceptionally warm years in Svalbard (Longerbyen airport weather station). Climate warming has been accompanied by an increase in annual precipitation on average by $6.2 \mathrm{~mm}$ per decade (3.2\% per decade relative to the period of 1961-1990. The Ny-Ålesund station showed even larger increase ( $8 \%$ per decade), much of which is due to single events of large amounts of precipitation in the later years. The increase in precipitation is attributed mainly to the summer and autumn season. Recently, the warming rate observed in last few decades is attributed to the air mass characteristics and changes in sea ice extent. After the 2000, the occurrence of several warm years coincided with low sea ice concentration in the Arctic Ocean during summer. Such sea conditions lead to an increased heat absorption by sea water and higher surface temperatures during autumn season. Gjelten et al. (2016) reported a decrease in the number of cold days per year and an increase in the number of warm days. A decreasing inter-annual variability was observed as well. In winter, spring and autumn, the regions in the northernmost areas of west Spitsbergen and in the innermost parts of the Isfjorden were the coldest ones. In summer, however, the southernmost regions were the coldest ones.

Main consequences of the air temperature rise are changes in the duration of the snow cover, the cover of sea ice, permafrost and glaciers dynamics. Similarly to the abiotic components of Svalbard terrestrial ecosystems, both local fauna and flora respond to warming (see e.g. Wasowicz et al. 2020). Among the most important consequences, changes in structure and function of plant and animal communities (Descamps et al. 2017), altered biodiversity, and an increase in number of newly introduced species might be mentioned. Future changes in stability of terrestrial ecosystems are predicted as well. Therefore, the evaluation of Arctic terrestrial eco- 
systems components response to warming is of major importance for their future behavior.

Climate change brings several challenges to the Arctic. Global climate change may increase human activities in the Arctic that create potential for economic development. Among them, mining, oil and gas industry, shipping, fisheries and tourism could be promoted. On the other hand, these economic benefits pose a risk to the environment, local populations and traditional livelihood of the Indigenous people. These challenges further affect different sectors such as e.g. environmental, economic, geopolitical, military, legal and societal (Padrtová 2019). In order to understand the complexity and strategic implications of the challenges in the Arctic, there is a need to investigate dynamics of development in a broader interdisciplinary context of related sectors.

Our research focuses on both the challenges and risk assessment in terrestrial ecosystems. Research team investigates the relation of the natural environment changes to the human-to-environment interaction, as well as the consequences for the geopolitical, legal and security developments in the Arctic region. Based on gained findings, the team will develop risks analysis and recommendations for mitigating the impact of environmental changes on the natural environment and population in specific Arctic territories. Due to the global character of the analyzed challenges and also interdisciplinary nature of the project, the research findings could be potentially applied beyond the Arctic region.

In order to reflect on the interdisciplinary nature of the research phenomenon and to address interdependencies of the research topics, the project establishes the Arctic Centre for Human-to-Environment Oriented Studies (ARCTOS) at Masaryk University (MU). The team is composed of scientists with different specialization and expertise in polar research from three MU faculties - Faculty of Social Studies, Faculty of Science and Faculty of Law. The Centre serves as a platform for enhancing future interdisciplinary research.

\section{Material and Methods}

Applying interdisciplinary approach enables answering specific questions that are too broad or complex to be adequately dealt with by a single discipline's method. The interdisciplinary approach integrates insights from all relevant disciplines and constructs more comprehensive perspective. It also provides solid background for investigation and understanding of the regional dynamics. At the same time, integrated research in which scientists coop- erate across disciplines contributes to a better understanding of many multi-dimensional problems. Fig. 1 brings visualization of specific topics and challenges that are divided into five leading themes - Natural risks assessment; Challenges caused by human activities; Geopolitical challenges; Common security challenges; Military challenges; and one cross-cutting theme: legal regime. 


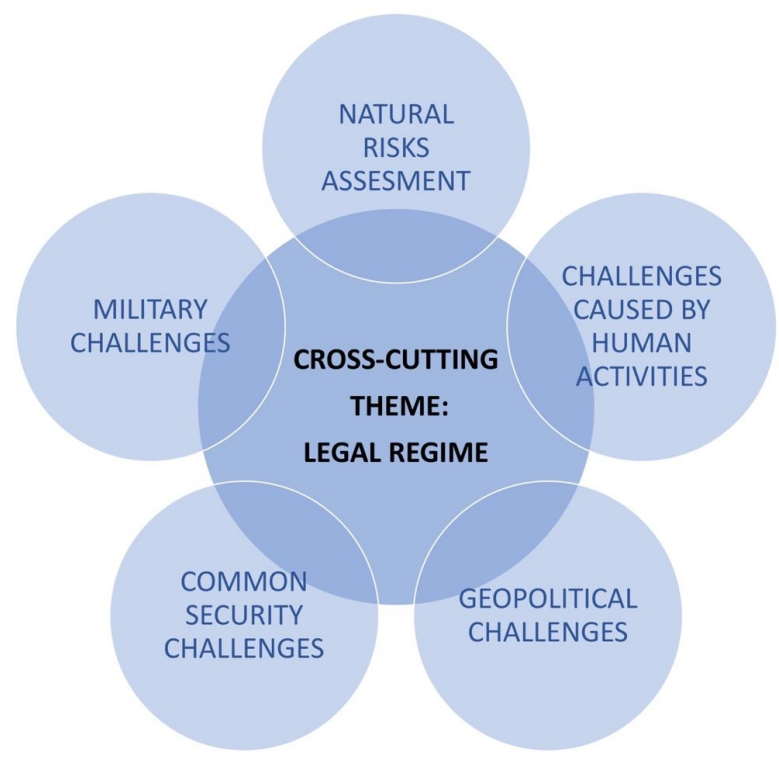

Fig. 1. Main themes of the research.

\section{Natural Risks Assessment}

The team studies landscape evolution (deglaciation), changes in selected terrestrial ecosystems dynamics (succession) and response to climatic forcing in a case study territory of Svalbard Archipelago. The Natural risk assessment (NRA) has three main focus areas: (1) microclimate, (2) pollution of microhabitats, and (3) changes in ecosystem structure. The research team investigates what kind of natural risks can be observed in the Arctic and evaluates their importance. These include climate to microclimate analysis (see Fig. 2) with the relation to ongoing deglaciation and melting of permafrost (Aars et al. 2017, Láska et al. 2012). The team focuses on key processes and their impacts on natural environment (abiotic and biotic) components. This relates to monitoring and observations of key environmental variables in the central Svalbard. Climate change effects on the landscape is studied by a case study: glacier retreat and its effects on lake ecosystems including its physicochemical com- position and heterotrophic/autotrophic terrestrial communities including soil crusts (e.g. Sehnal et al. 2014). The team also analyzes the available data - aerial photos, atmospheric and climate parameters, soil and water samples as well as microbiological samples in terms of biodiversity and physiological functioning (MS in prep. for Biodiversity of Bjorndalen, W of Longyerbyen). The research includes standard methods used in polar ecology including ecophysiology of photosynthesis (see e.g. Barták et al. 2012, Hájek et al. 2016). In order to monitor environmental processes and their relationship to climatic forcing, dataloggers and sensors in different habitats will be installed. Set of research plots will be established at different habitats and along the altitudinal gradient for evaluation of changes in vegetation cover. For analysis of succession dynamics after deglaciation, water/soil and biological sampling will be conducted in the field. 


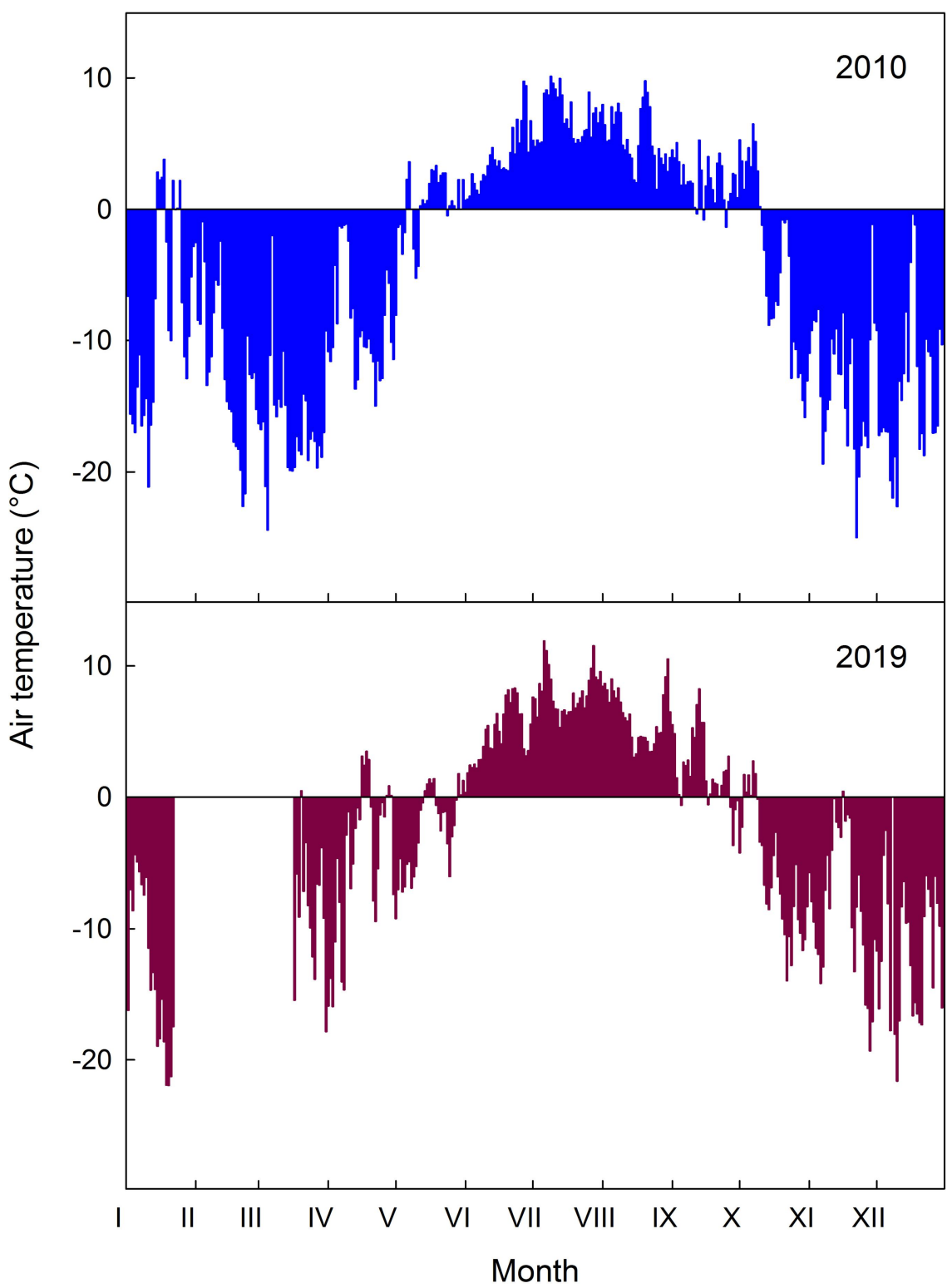

Fig. 2. Calculated daily means of air temperature measured at the research plot in Adventdalen for 2010 and 2019. (Source data: [2] - UNIS Weather station, Adventdalen).

Air temperature is considered one of the most sensitive indicators of climatic changes. Recent study of Wawrzyniak and Osuch (2020) reports global climate changeinduced increase in annual means of minimum, mean and maximum temperatures re- corded in Horsund region (Svalbard) for last 40 years. However, it is well established that climatic variables such as air temperature, and other vary significantly across the Svalbards archipelago (Nordli et al. 2014, Osuch and Wawrzyniak 2017). 
Moreover, yearly courses of air temperature show interannual differences as well (see Fig. 2 for Adventdalen, Svalbard). Interseasonal differences are apparent for the 2010 and 2019 data. In general, the interseasonal differences are caused by the changing Arctic climate system and atmos-

\section{Challenges Caused by Human Activities}

With the opening up of the Arctic (caused especially by melting of the seaice and milder climate conditions in general), natural environment experiences severe anthropogenic pressure connected to the increased human activities (Schönfeldt 2017). These economic activities include exploration of natural resources, new shipping routes, mining and recently also boom of tourism. All these activities mean development of new or improvement of present infrastructure - airports, harbors or roads. Increasing socio-economic activities are also connected with the expansion of local pollution production, especially from the traffic and electricity. In addition, new and easily accessible areas of the Arctic attract travel agencies and their clients to explore the Arctic. This rapidly increases the number of incoming persons to Svalbard and other areas. Such anthropogenic loads results in an invasion of species of plants and especially microorganisms which are nonnative. These invasive alien species are studied especially in the neighborhood of formal/recent settlements. The research follows up on a study of Tomczyk and Ewertowski (2010) who evaluated the changes in human impact on selected components of the environment. The authors monitored the human impact and categorized three subgroups of effects: (1) mining activity and transport of natural resources, (2) newly formed paths due to transportation and tourist activities, and (3) small-scale impacts like e.g. campsites and fireplaces). pheric circulation in particular year. The interannual differences in air temperature are of crucial importance since they have local feedback on many environmental components. Therefore, the local climate may have impact on natural risks of particular localities on Svalbard.

Increasing pollution in the Arctic represents another recent problem (Pakszys et al. 2020). Pollutants in the Arctic are mainly transported from southerly latitudes by winds, ocean currents and rivers. For Svalbard, contamination and sources of pollution have been reviewed recently by Granberg et al. (2019) who described polluted sites and their sources in Svalbard and identified current available remediation options. They also provided a guidance on the future actions regarding polluted sites in Svalbard. In general, pollutions affect significantly the environment and local food chain, and therefore affect local communities. In addition, the team investigates resistance of selected autotrophs to pollutants, the socio-economic developments enabling the raise of tourism industry, and the scope of international law which governs the Arctic affairs in this context. The impact of climate change and human presence are studied in the selected tourist areas in Svalbard (Longyerbyen, Pyramiden). The research includes representative number of tourists and sampling from their clothes/shoes in the areas around the infrastructure of the Czech research station. The ability of organisms to settle in the local environment will be tested by direct observations and sampling from soil and freshwater environment for selected microorganism. Human impacts in a landscape scale will be evaluated by GPS-localized photography. 


\section{Geopolitical Challenges}

The geopolitics in the Arctic has been influenced by the current international relations' developments and increasing tensions between Russia and the West. Additional drivers for geopolitical challenges are the availability and accessibility of energy resources (mainly oil and gas) and opening of new transportation routes (Vlček et al. 2019a, b) for destination improvement of port infrastructure (e.g. Nyman et al. 2020), transit shipping and the legal aspects thereof. We investigate the importance of emerging Arctic shipping routes in relation to global traffic routes and the economical and geopolitical potential of this phenomenon. The main goal of the research is to analyze geopolitical challenges posed by the intensive Russian Arctic strategies to develop Arctic areas, transit routes, resource deposits and (namely nuclear) technologies enabling supply of electricity in remote areas. This is, for example, manifested by the maintenance and development

\section{Common Security Challenges}

There are two major types of security issues facing the Arctic: issues related to military security of individual Arctic states and those relating to the common security of multiple regional states. The common security deals mainly with threats of piracy, terrorism and environmental disasters in the region (Heininen et al. 2019, Kř́ž and Padrtová 2016). Arctic countries retain military presences in the High North to project their influence in the region and to protect their national security. However, a national military presence cannot solve cross-border issues alone, hence the international cooperation among the Arctic states is required. The states use cooperation frameworks to mitigate environmental disasters, such as oil-spills or pollution, to deal with threats such as terrorism and of the nuclear icebreaker fleet or floating nuclear power plant, with Russia being the only country with these technologies. In addition, the team also studies the economic aspects and the new cooperation ties with their influence on international relations (i.e. the route to transport Chinese goods to European ports is substantially shorter and cheaper using the Russian Northern Sea Route). The analysis focuses on current geopolitical trends and the reflection of the Arctic affairs in the international law. To understand the geopolitical challenges combination of different methods of text analysis will be applied. The team applies a single-case study to provide an in-depth look inside the policy making process. To collect the necessary data, methods of both qualitative and quantitative content analysis are used along with the instruments of semi-structured interviews with relevant stakeholders.

smuggling which are essential for common safety (Akcayoz De Neve et al. 2015). The team investigates the impact of climate change on security developments and relations among states and relevant stakeholders in the region. The research focuses on how geopolitics transforms into policy and what are the key variables that influence the relations of cooperation/competition among states in the region. Main emphasis is given to international law that governs the Arctic affairs in the context of common security challenges. Common security threats are investigated based on data collected via analyzing primary public sources of information (national and security strategies), conducting semi-structured interviews with top-officials, academics and high-ranked officers of the Arctic states. 
For data analysis the comparative method and content analysis are used. The research is further reinforced by triangulation of

\section{Military Challenges}

In the past centuries military forces in the Arctic has been largely rooted in exploration and colonial expansion, before exploring the technological and geopolitical developments that led some strategists and polar experts to militarize the region. The militarization of the Arctic served as both a response to global geopolitical tensions and as a source of intensified tensions. The military activities and development that enabled and flowed out of this process irrevocably changed the region: militarily and politically, but also socially, culturally, and environmentally (Kikkert and Lackenbauer 2020). However, in the last decades, melting ice reopens northern borders and shipping lanes. The climate crisis is increasing geopolitical tensions, as well as intensifying a new military buildup in the Arctic, such as reopening of old cold war bases and ports. Hence, the militaries of each Arctic state have to adapt on the new situation. The military transformations of individual Arctic states are observed, especially in relation to ongoing climate

\section{Cross-cutting Theme: Legal Regime}

The legal regime of the Arctic is based on the fragmented international public law (both hard law and non-binding soft law mechanisms) and domestic law (Uhlírová and Drumbl 2018). These regimes and specific rules intersect and interact, making the Arctic governance very complex and multifaceted (Uhlírová and Drumbl 2020). The research reveals a multitude of issues and challenges such as an access to natural resources in the Arctic, geopolitical and security challenges or adaptation of individual Arctic states' armed forces to climate data collected during the research field trips in several locations in the Arctic.

change. The research identifies existing differences in military reforms and shifts in the distribution of military power. The research aims to investigate whether an extensive militarization of the Arctic is a real possible scenario for the future (Kříž and Chrášt'anský 2012). The research findings contribute to a better understanding of the power distribution changes that are noticeable in the region. The research also evaluates whether or not the existing latent disputes in the Arctic are likely to escalate into armed conflicts. In addition, the team investigates how the use of force is reflected in the international law. The research data will be collected via analyzing primary public sources of information (military doctrines, national strategies, security strategies), and conducting semistructured interviews with top-officials, academics and high-ranked officers of the Arctic states. The process of military reforms in specific Arctic states will be analyzed by a data process tracing method.

change, which could not be grasp comprehensively without the investigation of legal framework. Therefore, the legal part develops a comprehensive understanding of the practical role which international law plays in the context of Arctic governance. The research team analyzes the challenges related to the Arctic from the point of international law (the international environmental law, the law of the sea, the human rights law, the international treaty law, the law of international organizations). The law in the Arctic is the only functional instru- 
ment for cooperation in the region and serves as a foundation for development in all respective sectors. The international law aspects in respective are investigated through analysis of hard and soft law mech-

\section{Discussion and Conclusions}

The uniqueness of the project lies in the combination of several research disciplines applied on the case study of the Arctic region. This approach enables to grasp the complexity of individual research topics. The research reveals a multitude of issues and challenges in the Arctic, which would not be possible to adequately address and understand by a single discipline's method. These include natural risks of the climate change and impacts on the natural environment (connection to human activities and environmental law), availability and accessibility to the natural resources (connection to energy security and international law), geopolitical and security challenges (directly connected to the domestic and international law) and adaptation of individual Arctic states' armed forces to climate change (domestic and international law). Investigation of these aspects helps to understand the complexity of Arctic de- anisms based on primary and secondary sources (multilateral and bilateral treaties, UN documents, official statements, diplomatic correspondence). velopment and adaptations to ongoing climate change. These aspects have not been analyzed yet neither at Masaryk University nor at the international level.

In addition, the project is unique due to its specific science communication and dissemination of research findings, which aims at four levels of audience: (i) academic community, (ii) policymakers, (iii) general public, and (iv) students. Also, the project supports inclusion of young female scientists. Moreover, the research findings will increase the prestige of the Czech polar research on the international level by its contribution to global meta-databases about the climate change effects in the Arctic. By the establishment of the ARCTOS $\mathrm{MU}$, the interdisciplinary research team will be able to foster the long-term cooperation and potentially offer further involvement of other research disciplines in the future.

\section{References}

Aars, J., Marques, T. A., Lone, K., Andersen, M., Wiig, Ø., Bardalen Fløystad, I. M., Hagen, S. B. and BuCKLAND, S. T. (2017): The number and distribution of polar bears in the western Barents Sea. Polar Research, 36: 1374125.

Akcayoz De Neve, P., Heal, A. and Lee, H. (2015): Security of the Arctic: As the U.S. Takes Over the Arctic Council Leadership in 2015. Belfer Center for Science and International Affairs, Harvard Kennedy School, USA. https://www.belfercenter.org/sites/default/files/files/ publication/Arctic\%20Security\%20Policy\%20Brief.pdf

BARTÁK, M., VÁCzI, P. and HÁJEK, J. (2012): Photosynthetic activity in three vascular species of Spitsbergen vegetation during summer season in response to microclimate. Polish Polar Research, 33(4): 443-462.

Descamps, S., Aars, J., Fuglei, E., Kovacs, K., Lydersen, Ch., Pavlova, O., Pedersen, A., Ravolainen, V. and Strøm, H. (2017): Climate change impacts on wildlife in a High Arctic archipelago - Svalbard, Norway. Global Change Biology, 23: 490-502, doi. 10.1111/gcb.13381.

Gjelten, H., Nordli, Ø., Isaksen, K., Førland, E., Sviashchennikov, P., Wyszyński, P., Prokhorova, U., Przybylak, R., Ivanov, B. and Urazgildeeva, A. (2016): Air temperature 
variations and gradients along the coast and fjords of western Spitsbergen. Polar Research, 35 : 29878, http://dx.doi.org/10.3402/polar.v35.29878.

HáJek, J., BARTÁk, M., Hazdrová, J. and ForbelskÁ, M. (2016): Sensitivity of photosynthetic processes to freezing temperature in extremophilic lichens evaluated by linear cooling and chlorophyll fluorescence. Cryobiology, 73(3): 329-334.

Heininen, L., Everett, K., PadrtovÁ, B. and Reissell, A. (2019): Arctic Policies and Strategies - Analysis, Synthesis, and Trends. Laxenburg: IIASA, 2019. 263 pp. ISBN 978-3-7045-0156-1. http://pure.iiasa.ac.at/id/eprint/16175/1/ArticReport_WEB_new.pdf

KikKert P., Lackenbauer P.W. (2020): The Militarization of the Arctic to 1990. In: Coates K., Holroyd C. (Eds.): The Palgrave Handbook of Arctic Policy and Politics. Palgrave Macmillan, Cham, pp. 487-505.

KŘí̌̌, Z., ChRÁŠŤAnskÝ, F. (2012): Existing Conflicts in the Arctic and the Risk of Escalation: Rhetoric and Reality. Perspectives, Prague: Institute of International Relations, 20/1, pp. 111140.

Kř́žz, Z., PADRTovÁ, B. (2016): The Moscow Times as a Securitization Actor of the Arctic Topic From 2007 To 2014. In Group Authors. Conference: International Multidisciplinary Scientific Conferences on Social Sciences and Arts. Sofia: SGEM, 2016. pp. 397-404, ISBN 978-6197105-73-5.

LÁskA, K., WitoszovÁ, D. and ProŠEK, P. (2012): Weather patterns of the coastal zone of Petuniabukta, central Spitsbergen in the period 2008-2010. Polish Polar Research, 33: 297318.

Nordl, Ø., Przybylak, R., Ogilvie, A. E. J. and Isaksen, K. (2014): Longterm temperature trends and variability on Spitsbergen: The extended Svalbard Airport temperature series, 1898 2012. Polar Research, 33: 21349, https://doi.org/10.3402/polar.v33.21349.

Nyman, E., Galvao, C., Mileski, J. and Tiller, R. (2020): The Svalbard archipelago: an exploratory analysis of port investment in the context of the new arctic routes. Maritime Studies, 19: 1-13. doi: 10.1007/s40152-019-00143-4.

OsUCH, M., WAWRZYNIAK, T. (2017): Inter- and intra-annual changes of air temperature and precipitation in western Spitsbergen. International Journal of Climatology, 37: 3082-3097. https://doi.org/10.1002/joc.4901.

PADRTOVÁ, B. (2019): Frozen narratives: How media present security in the Arctic. Polar Science, 21: 37-46. doi:10.1016/j.polar.2019.05.006.

Padrtová, B., TrÁvníčKovÁ, Z. (2017): The Arctic Research Report: Political-Security, Economic and Scientific-Research Aspects. Analysis for the Ministry of Foreign Affairs of the Czech Republic, Institute of International Relations, Prague. 97 p.

PAKszys, P., Zielinski, T., Fererro, L., KotynskA-Zielinska, I. and Wichorowski, M. (2020): Changing Arctic. Firm scientific evidence versus public interest in the issue. Oceanologia. 10.1016/j.oceano.2020.03.004.

Sehnal, L., BARTÁK, M. and VÁCZI, P. (2014): Diurnal changes in photosynthetic activity of the biological soil crust and lichen: Effects of abiotic factors (Petuniabukta, Svalbard). Czech Polar Reports, 4(2):158-167.

TOMCZYK, A., Ewertowski, M. (2010): Changes of Arctic landscape due to human impact, north part of Billefjorden area, Svalbard. Quaestiones Geographicae, 29: 75-83.

UhlířovÁ, K., Drumbl, M. (2018): International Environmental Law, Washington \& Lee Legal Studies Paper, No. 2018-05.

UhlířovÁ, K., Drumbl, M. (forthcoming 2020): Actors and Law Making in International Environmental Law, in M. Fitzmaurice, M. Brus and P. Merkouris (eds.): The Research Handbook on International Environmental Law. Cheltenham: Edward Elgar Publishing. 50 p.

VlČEK, T., BodišovÁ, L. and VencourovÁ, Ž. (2019): The Northern Sea Route: Oil Transportation Alternative for Current Sea Lanes of Communication? Politologický časopis, Brno: Masaryk University, 2019, 26/1, pp. 50-73. ISSN 1211-3247. doi:10.5817/PC2019 150.

VLČEK, T., JIRUŠEK, M. (2019): Russian Oil Enterprises in Europe - Investments and Regional Influence. Cham, Switzerland: Palgrave Macmillan, 238 p. $1^{\text {st }}$ Edition. ISBN 978-3-030-198381. doi:10.1007/978-3-030-19839-8. 
Wasowicz, P., Sennikov, A. N., Westergatrd, K. B., Spellman, K., Carlson, M., Gillespie, L. J., SaArela, J. M., Seefeldt, S., Bennett, B., Bay, Ch., Ickert-Bond, S. and VÄre, H. (2020): Non-native vascular flora of the Arctic: Taxonomic richness, distribution and pathways. Ambio, 49: 693-703. doi: 10.1007/s13280-019-01296-6.

WAWRZYNiak, T., OsUCH, M. (2020): A 40-year High Arctic climatological dataset of the Polish Polar Station Hornsund (SW Spitsbergen, Svalbard). Earth System Science Data, 12: 805-815. https://doi.org/10.5194/essd-12-805-2020.

\section{Web sources / Other sources}

[1] AMAP Assessment 2011: Mercury in the Arctic. Arctic Monitoring and Assessment Programme (AMAP), Oslo, Norway. 193 pp. ISBN 978-82-7971-068-4.

https://www.amap.no/documents/doc/amap-assessment-2011-mercury-in-the-arctic/90

[2] UNIS Weather station, Adventdalen; https://www.unis.no/resources/weather-stations/ 